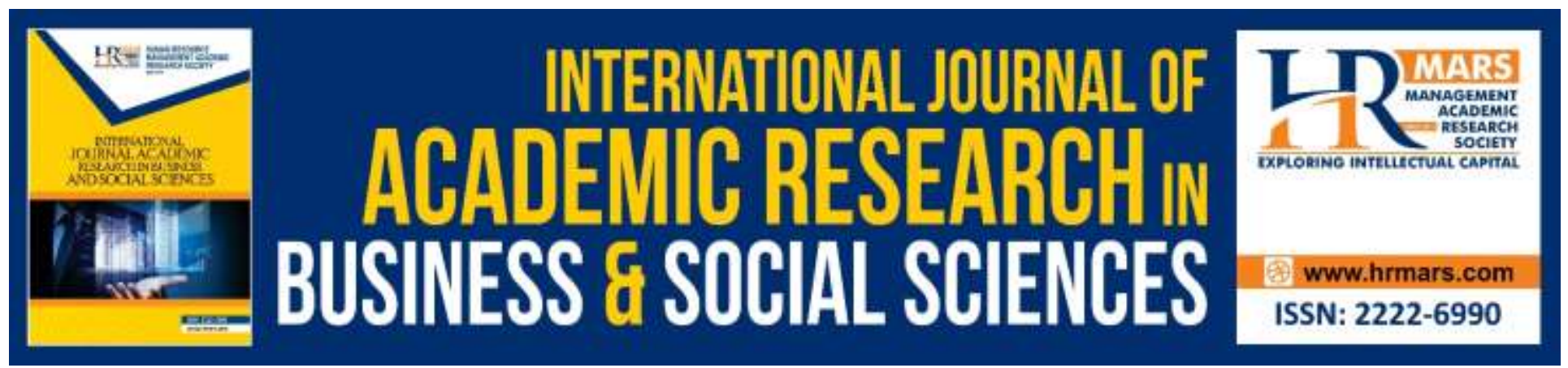

\title{
Succeeding Change Management of Passenger Service through the Initial Stage. Study at PT Kereta Api Indonesia (Persero)
}

Agus Priyanto, Sam'un Jaja Raharja, Anang Muftiadi, Suryanto

To Link this Article: http://dx.doi.org/10.6007/IJARBSS/v10-i2/6859

DOI:10.6007/IJARBSS/v10-i2/6859

Received: 02 January 2020, Revised: 25 January 2020, Accepted: 30 January 2020

Published Online: 09 February 2020

In-Text Citation: (Priyanto et al., 2020)

To Cite this Article: Priyanto, A., Raharja, S. J., Muftiadi, A., \& Suryanto. (2020). Succeeding Change Management of Passenger Service through the Initial Stage. Study at PT Kereta Api Indonesia (Persero). International Journal of Academic Research in Business and Social Sciences, 10(2), 45-56.

\section{Copyright: (C) 2020 The Author(s)}

Published by Human Resource Management Academic Research Society (www.hrmars.com)

This article is published under the Creative Commons Attribution (CC BY 4.0) license. Anyone may reproduce, distribute, translate and create derivative works of this article (for both commercial and non-commercial purposes), subject to full attribution to the original publication and authors. The full terms of this license may be seen

at: http://creativecommons.org/licences/by/4.0/legalcode

Vol. 10, No. 2, 2020, Pg. 45 - 56

Full Terms \& Conditions of access and use can be found at http://hrmars.com/index.php/pages/detail/publication-ethics 


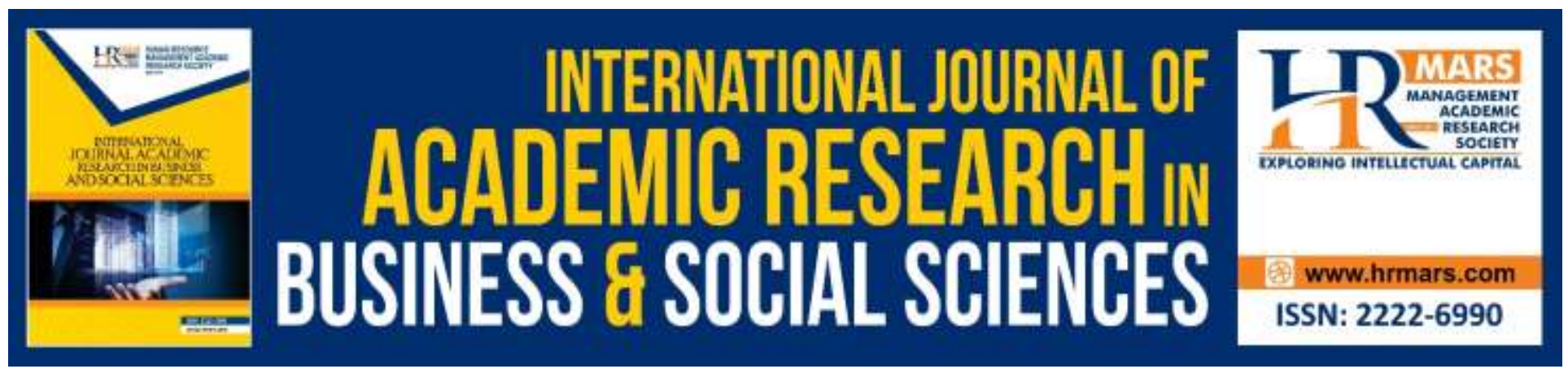

\title{
Succeeding Change Management of Passenger Service through the Initial Stage. Study at PT Kereta Api Indonesia (Persero)
}

\author{
Agus Priyanto, Sam'un Jaja Raharja, Anang Muftiadi, Suryanto \\ Padjadjaran University
}

\section{Abstract}

Change management in initial stage is an important part of organizational change because it becomes the starting point of a series of subsequent stage change programs. In fact, starting a change program is not easy and requires extra energy. This phenomenon is interesting to study but unfortunately the studies focuses on this topic have not been done much. So, this is the reason behind the selection of this article. This article purposes to find out how the implementation of the change management of PT Kereta Api Indonesia (Persero) in the initial stage so that it can encourage the success of the company in changing passenger services.

This research uses a qualitative method with an explanatory descriptive approach. Key informants were selected as many as 12 staffs from the passenger services section who were directly involved in the change process. Primer data collection is done through in-depth interviews. While supporting data obtained through qualitative observations and literature studies.

Results showed that change management was implemented by instilling employee's awareness of change through understanding the importance of change and its consequences. Furthermore, change management closes by reinforcing the desire to change from resistance to acceptance to change by growing motivation for employees.

Keywords: Change Management, Organizational Change, Awareness, Desire, and Motivation.

\section{Introduction}

Starting to change in an existing organization is much more difficult than building a new one. This statement is acceptable since organizational change is not just to restructure, to reengineer, or to transfer technology but it must touch on changing the mindset of individuals as the driving force of the organization (Carnal, 2007). A reasonable explanation is needed so that it can be accepted by all parties who will be affected by the change. In fact, There are still many people who can't accept change because change can interfere with their comfort and position. To deal with this resistance, change management exists as an alternative solution for the organization. 
Change management is a process that begins with refreezing (Lewin, 1951), an effort to dilute the mindset that has been embedded in the minds of members of the organization. This stage plays an important role because it becomes the foundation for the next stage. But, it must be remembered that inviting someone to start a change is not easy. People are usually reluctant to be invited to change before understanding what change like is and why change is needed. Resistance to change also arises when people feel uncomfortable with the change management (Coch \& French as cited in Burnes 2014). The solution that can be taken is to create a sense of urgency in each individual (Kottler, 1996). Awareness of the sense of urgency will be formed after people understand the meaning of change, see evidence of change, know the purpose of change, and realize the consequences that will be accepted if they do not make changes (Zimmerman, 2005).

This article aims to reveal the implementation of change management in the initial stage at PT KAI. Now days, there has been a lot of researches related to change management, but only a few focused on management of change in the initial stages. Therefore, the results of this study are expected to fill the gap of these shortcomings and it will add to the repertoire of references for researchers who will conduct research related to the topic of change management. Whereas the reason for choosing PT KAl as the location of the research focus was because of the company's success in implementing change management.

\section{Literature Review}

The study of organizational change is an endless topic in the business world. The study will continue to develop over time. The study of organizational change is an interdisciplinary study of several fields, such as psychology, sociology, economics and management (Black as cited in Burnes, 2009 , p. 183). Then, what does organizational change really mean? Organizational change is a process of transition from current conditions to the conditions expected in the future by utilizing all the potential possessed (Conner, 1992, p. 6). Another definition states that organizational change is an effort to maintain the organization in its present condition and can continue to live in the future (Robbin 1994, p. 418). Meanwhile, Kundray and Klainer (as cited in Davidson, 2005, p. 4) defined organizational change as an ongoing alignment process of an organization with its market more responsive and effective than its competitors.

Changes in business organizations are common sight. There are several factors that drive organizational change including business, technology, financial competition (Chandler, Jr., as cited in Berger, 1994, p. 24), and demands for environmental change (Watkins \& Mohr as cited in Rashford 2006, p. 47). While the goals of organizational change include: an effort to adapt to changes in the environment that are increasingly difficult to predict, respond to increasingly fierce business competition, and efforts to realize the stated organizational goals. (Van de Ven \& Pole, 2004, p. 89).

Organizational change itself consists of several forms. Anderson \& Anderson (2001, pp. 32-43) distinguish organizational change based on the scale of output achieved into: a) Developmental change, change at the lowest level where the changes made are still limited to improvements to existing institutions without accompanied by a breakthrough new; b) Transitional change, an effort to combine existing institutions with several new breakthroughs in efforts to make adjustments to answer the challenges of future environmental change; c) Transformational change, an attempt to change radically from previous condition to new condition. 
Various thoughts of organizational change emerge inspired by the ideas of Lewin (1951), such as organizational development theory, management theory and several other theories. However, there is one important thing to note that organizational change must be based on several ideas about the psychological nature and personality of workers (Collin, 1998, p. 4). So, whatever its forms and its names, organizational change must touch on human dimensions such as motivation, cooperation, commitment, trust and organizational values. This is the only way in order to change will have value. Without touching this dimension, change will only be short-lived. (Kasali, 2005, p. 112). This human dimension inspires the emergence of change management theory.

The emergence of change management idea is motivated by the failure of various companies in carrying out organizational change projects. Harrington et al., (2000, p. 5) show some examples of research results about the failure include: 1 ) Standish Group research results show the failure of the application of information technology programs in business processes in large companies that almost reached $91 \%$, even more than $30 \%$ postponed before implementation; 2) Scheinmann's research proves that the failure of the organizational change program by companies listed in the Fortune 500 reached more than 50\%; and 3) recognition of Hammer (as cited in Salaman \& Asch, 2003, p. 9) for the failure of reengineering practice. More sources of failure are caused by the absence of the human dimension in the project of organizational change.

Change management offers practical advice to managers in dealing with rapid environmental changes. There is an important thing to know that change management is different from organizational change. The absence of a clear portrayal will give rise to confusion and lack of clarity about what is needed to advance change initiatives (Creasey, 2018). Organizational change is the movement from current conditions towards future conditions, while change management is an encouragement to every individual affected by change during their transition - from current conditions to future conditions. The picture of the two terms looks like the following picture:

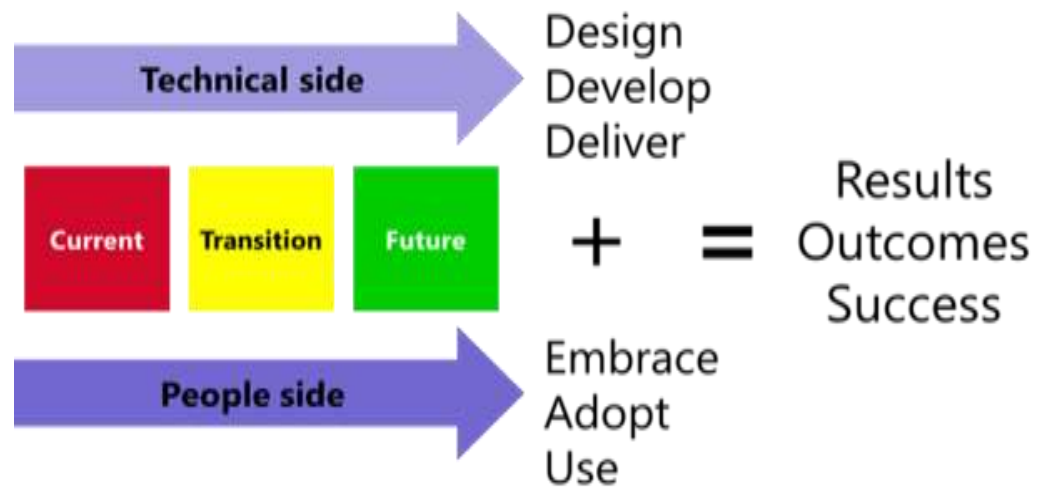

Figure 1

Organizational Change Perspective

The picture above shows that in order to achieve success in an organizational change program, organizations must consider two sides equally, namely the technical side and the human side as the parties affected by these changes. The technical side refers to how to design, develop, and implement 
programs (such as restructuring and mergers), run effectively and efficiently. While the human side refers to how to embrace, to lift and to empower members of organizations affected by change to accept and to play a role in change at the same time.

Lewin (1951) explains in his theory that change is analogous to sawing a block of ice. Through the strategy put forward by Lewin, the supporting forces will be more numerous and the forces of resistance will be less. Broadly speaking there are three basic activities of the process of organizational change. First, the change process begins with the identification of problems that will arise at the beginning of the change program. Identification activities are followed by efforts to create motivation in order to unfreeze changes in attitudes towards work practices. In order for activities to go according to plan, the change program must be communicated to all elements of the organization so that it can be fully understood and implemented. The identification process must not only be based on assumptions but must be supported by accurate information sourced from valid data.

Second, the stage where the organization moves through the process of change (change). The data that has been collected is analyzed in order to obtain accurate information as a basis for formulating a plan for change. When the plan has been prepared, it needs to be immediately implemented in practical activities and followed up with stabilization of the changes that have been made. As an evaluation of the implementation of change, an assessment of the consequences of changing the attitudes and behavior of all members of the organization is needed.

Third, the process ends when the organization returns to a sense of stability (refreeze) and the realization of the benefits of change, which is needed to create trust to begin the next inevitable change. Praise, appreciation and other reinforcement by managers is needed the individual level and more effective performance at the organizational level as a form of learning from a process. The patterns of the three activities above can be described as follows:

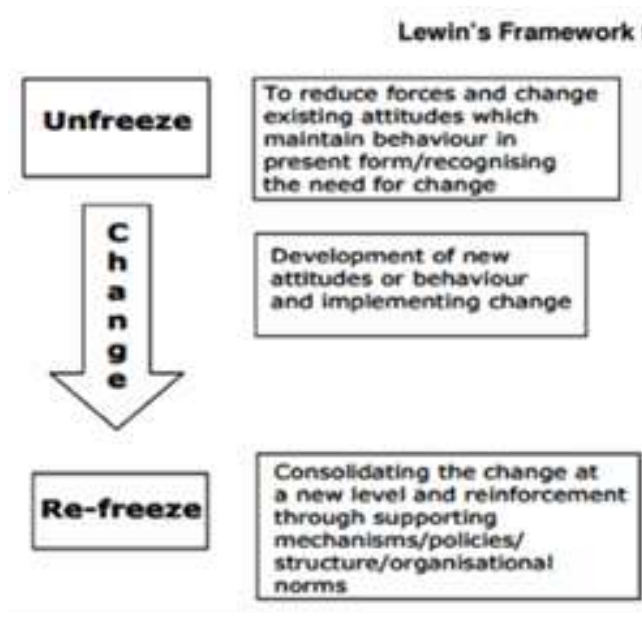

1. Initial problem Identification

2. Preparing the ground and

. Obtaining data

3. Obtaining data

4. Problem diagnosis

5. Action planning

6. Implementation

7. Follow up and stabilisation

8. Assessment of consequences

8. Assessment of consequences

9. Ongoing monitoring

10. Learning from process

Gambar 2.1

Lewin's Frame of Change 
A change management model from the individual perspective was introduced by Hiatt \& Creasey (2003), known as the ADKAR Model. ADKAR is an acronym of five dimensions that are sequential describe the stages or phases that must be taken by every company in implementing change management. Thus five dimensions are:

a. Awareness refers to the awareness of every individual understanding the importance of the change program being carried out by the organization and the consequences that will be received if it is not implemented.

b. Desire refers to the desire of every individual to reject or support change because change always presents pros and cons depending on each individual's perception of the change program.

c. Knowledge refers to the knowledge and skills possessed by each individual to deal with changes so that they do not experience obstacles in carrying out their functions in the change program.

d. Ability refers to the potential possessed by individuals that are personal and are usually not obtained through training programs or formal education but through practice or direct experience in the field such as communication, empathy, emotions, self-confidence, and responsibility.

e. Reinforcement refers to the commitment of each individual to maintain a new system or work pattern not as a burden but as a pleasant thing so that they are happy to explain it.

The five dimensions can be described as follows

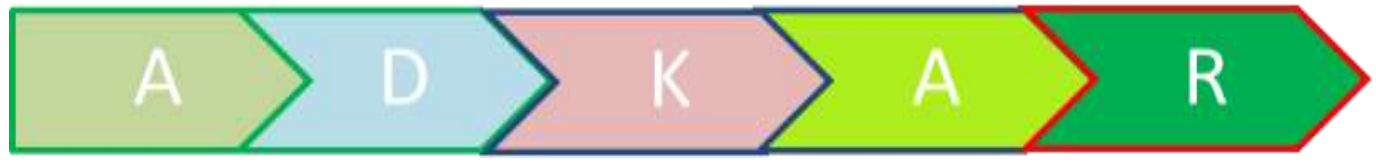

Figure 2

Change management ADKAR Model

Based on the picture above, thus five dimensions can be classified into three part based on the stages of the change. Dimensions of awareness and desire are two dimensions that are in the initial stages of change (unfreezing). Dimensions of knowledge and abilities are the two dimensions that are at the stage of implementing change. The last, dimension of reinforcement dimension is a dimension that is at the stage of strengthening change (refreezing). In this article, the theory of change management from Hiatt \& Creasy (2003) is chosen as the theoretical foundation for conducting analysis. Since the purpose of the research is to find out the management of change at an early stage, this article will focus on the dimensions of awareness and desire.

\section{Research Method}

This research was conducted to obtain a picture of how the practice of changing management in passenger service carried out by PT KAI in the early stages by exploring all aspects related to aspects of change management so that researchers understand the process of change management in depth. In accordance with its objectives, the approach used in this study is qualitative. Primary data were obtained through interviews with 12 key informants namely passenger service staff who have worked 
INTERNATIONAL JOURNAL OF ACADEMIC RESEARCH IN BUSINESS AND SOCIAL SCIENCES

Vol. 10, No. 2, Feb, 2020, E-ISSN: 2222-6990 @ 2020 HRMARS

for more than ten years with the consideration of the informants directly involved in the process of changes made in the passenger service unit so that they have adequate information. Secondary data was obtained through qualitative field observations and literature study.

\section{Result}

Change management practices at the initial stage consist of awareness and desire dimensions. The result showed awareness has grown among the employees of PT KAI. The process of awareness building begins with understanding the definition of change. Understanding change is very important because someone will not accept and make changes before knowing what the definition of change itself. Generally, employees define change as follows:

1) Change as a process of improvement.

Change is considered as an effort to repair and a transition from things that are not good to be good or better in order to follow the development of the environment. For some people change does not have to replace with something new but simply by doing repairs to something that already exists. Change does not always have to be frontal because it needs to consider the parties affected by the change (Abrahamson, 2004). The essence of change is the existence of better output than before and efforts to adjust to the environment.

This definition of change is classified as developmental change, namely changes that are at the lowest level because the changes made are still limited to improvements to existing institutions without being accompanied by new breakthroughs (Anderson \& Anderson, 2001). The effects of change are also very small and can not meet the challenges of environmental change, especially in the future. Another term for changes is incremental change because it only revolves around the problem of adjustments in systems, processes, and structures but does not involve fundamental changes (Palmer et al., 2006).

2) Change as an innovation.

Change is considered as an improvement effort by using a new system or a device that has never been used before. Change is extreme because it is very different from the previous system or some call it innovation, a change whose output is better service than before and more emphasis on the need for solutions to obstacles in the field. The word innovation itself comes from the Latin 'innovationum means an update, or change. Innovation is the introduction of new, better ways of doing things at work (West as cited in Sutrisno, 2010). Innovation can also be interpreted as a concept of the benefits of a product or service into the principles of value added or sustainable competitiveness to seize opportunities (Hitcher, 2006). It emphasis on the principle of value added that distinguishes innovation from invention. Innovation is categorized as transformational change, an effort to change from previous conditions into new conditions altogether. Transformational change is a change at the highest level. It takes a strong awareness of all elements of the corporation to prepare themselves to participate in change into a new environment that is completely different from the previous conditions (Anderson \& Anderson, 2001, p. 32-43).

The two meanings of change above came from the same word, change, but both of them had different backgrounds. Developmental change happened when environmental change was still not as fast as it is today and all can still be predicted so that the change can be planned (planned change). Meanwhile, transformational change happened when environmental change was getting faster and 
harder to predict, so that change was difficult to plan (unplanned change) and is accidental. Referring to the meaning of change above, it could be concluded that employees had understood the meaning of change well.

Awareness on change is not just to understand the definition of change but know the reasons why it must change as well. The results show that there are three reasons why employees want to change:

1) Demands to improve services to consumers

Employees' awareness on the importance of service quality was the first factor behind the change in PT KAI. The employees realized that the service system carried out by the company before the change was far from the service quality standards. The problem of poor service started from the ticket sales system that was still manual so that it was not effective and efficient. The second problem was travel services, especially at economy class because the number of passengers often exceeded the available seating capacity, which disturbed the comfort and safety of passengers. The third problem was that the facilities provided by the company in the waiting room such as seating and toilet facilities were still insufficient. Finally, the timeliness of departure and arrival is not in accordance with the specified schedule.

The employees realize that the services provided were no longer suitable to change times. The ease of payment transactions and the speed of access to information had become the demands of society and characteristic of the economic innovation of the current era. Finally, the employees concluded if poor service was continuously ignored, this condition would impact on the exodus of passengers to other transportation modes and could weaken the performance of the company.

The concept of service quality became so popular after Parasuraman who collaborated with Zeithaml and Berry wrote a book entitled "Delivering Quality Service: Balancing Customer Perception and Expectation" published by the Free Press in 1983. The three figures put forward the concept of service quality in terms of the gap aspect (gap analysis) where the quality of service was a level of discrepancy between the expectations or desires of consumers with the level of their perception. This concept was later better known as Servqual.

2) The importance of customers for the company

The awareness of employees to change their views about the importance of customers for the company was the second factor causing the company to make changes. Wrong views about customers had become the cause of the treatment to passengers not optimally. Previously, employees always assumed that passengers really needed a train. No matter how bad the form of services provided, passengers will still receive. These all are contrary to the new business principle oriented to quality service and customer satisfaction.

As a customer-oriented business organization, PT KAI had to adjust to the desires of its customers to maintain the survival of the company. The company had to keep abreast of the changing patterns of customer tastes as it is today who wants fast and easy service. The aim is to create customer satisfaction. In this case, concept of customer satisfaction is related to service quality. Both of them are a continuous series. Quality of service is a process while satisfaction is the result of that process. As a process, service will go through several stages starting from the production process to the consumption process. Among these processes there are service delivery processes that must be considered by service providers. 


\section{Competition}

The third factor behind the change in service at PT KAI was the presence of threats from competitors originating from other modes of transportation. Every company had to have a desire to compete continuously in the industry they work at. Moreover, it could reach a position as a market leader. Of course this was not an easy matter because every competitor also had the same desire. The existence of intense competition in fighting over the market required companies to have sustainable competitive advantage (Porter, 1985). Companies were required to be creative in creating an advantage that is not owned by competitors.

The company's commitment to build a new core competency was a commitment to perfect the benefits for customers, not a commitment to a certain market product opportunity. Investment in leadership competence could not only be judged on the contribution made by competence to leadership in one particular product category. Core competence was a set of skills and technology so that the development of core competencies more reflects the results of the accumulation of learning in various skills and various organizational units rather than in one small group. Therefore, competition for competence was not just competition between products, or between business units, but competition among corporations.

The ability of employees to identify the reasons for change was one of the keys to the success of PT KAI in implementing a change management program. Kotter (1996); Fery (2018) in his book entitled Leading Change suggests that to make a change, companies had to have a strong and rational reason so that it could be accepted by all elements because change would not proceed without the participation of all elements in it. In his idea, Kotter said that such a method was called to foster a sense of urgency to all individuals in the company.

The second dimension in the initial stage was desire. This dimension was difficult to control because it was outside management control. The result showed, employees of PT KAI were very enthusiastic to participate in the change. By referring to the theory of resistance from Conner (1992), the level of resistance to change in the employees of PT KAI had been at the level of acceptance. It was the last phase of resistance where people begin to look realistically at changes and realize the purpose of these changes. Employee involvement in change became a measure of the extent to which a person psychologically associates himself with his work and considers the level of performance as important to his self-esteem (Blau \& Boal as cited in Robbins, 2003: 268).

Someone did something because there was a motive that drove him called motivation, a process that played a role in determining the intensity, direction, and perseverance of individuals in an effort to achieve goals (Robbins, 2003: 213). The result showed the enthusiasm of the employees of PT KAI participated in the change was driven by two motivations:

1) Reward and punishment system.

The performance appraisal system at PT KAI was managed by the Assessment and HRD Unit, which collected employee performance data once a year. Performance data in the form of individual employee contained performance achievements for one year. Furthermore, the performance appraisal process was carried out through two stages, namely; the stage of gathering or adjusting the Performance Contract and the stage of performance appraisal.

The stage of collecting or adjusting a performance contract was carried out by nonimplementing workers domiciled at the Head Office, with the aim of having the standard 
performance contract. Worker's performance contract was derived from the target of his employer so that alignment met between the objectives of the Company and the objectives of its work units. The next stage was filling in the realization made by the direct supervisor at the beginning of the following year, to measure the achievement of workers against individual targets as outlined in the previous performance contract.

In addition to performance appraisals, the company also assessed employee competency. Competency assessment aimed to determine the level of knowledge, skills, personality and mental attitude needed in a position so that the position holder can carry out his duties effectively and meet organizational goals. To reduce the subjectivity factor, competency assessment was carried out using a 360 degree multi raters method, where each employee was assessed by the direct supervisor, coworkers, direct subordinates and themselves.

The results of performance and competency assessments became input for employee development plans, including performance improvement, compensation adjustments, placement decisions, training and development needs, career planning and development, efficient staffing, and objective feedback for subordinates and superiors. The application of the Reward \& Punishment system to an institution was intended to provide motivation to employees. Rewards were given as an appreciation for staff who excel or meet performance goals. Meanwhile, punishment was given as punishment or reprimand to employees who had committed violations or to employees who did not meet their performance goals. It turned out that this system was very effective in motivating employees to participate in the change management program launched by the company.

2) Help improve the company's image

Motivation to improve the image was a mandatory reason that was absolutely owned by the employees of PT KAI. As previously discussed, one of the reasons why companies made changes was the poor image of the company in the consumers' sight. The deterioration of the company's image was the accumulation of customer dissatisfaction due to the poor service provided by the company. So the only way to improve the company's image was to improve service or company performance.

Image was a group of associations formed in the minds of consumers (Rangkuti, 2002, p. 43). Image could also be interpreted as what people know about the company (Martineau as cited in Balmer \& Gresey, 2003; Chlapoutaki \& Dinas, 2016). Image was a powerful driver of customer behavior to buy goods or services. Image really helped a customer to distinguish between one product to another. Customers would find convenience in shopping when image had been built in mind.

When change began, thoughts of improving the company's image began to grow. Repairing an image that had collapsed would be far more difficult than building a new image because it had to go through a longer stage. Changing the bad image that had been attached in people's minds had to begin with removing the bad impression that already exists. After the bad impression had been erased, you could start to build a new image.

\section{Conclusion}

The success of PT KAI implemented change management in the early stages was supported by two factors, namely the success of creating employee's awareness of the significance of change and the success of managing the impacts caused by change. The success of creating awareness is 
characterized by the ability of employees to understand the meaning of change, understand the purpose of change and the consequences faced, and the ability to identify the factors behind the change. The three indicators above indicate that employees have been able to create a sense of urgency that is very beneficial for the company in making changes (Kotter, 1996; Maqbool, Ismail, Maqbool \& Hassan 2018).

The company's success in managing the impacts caused by change refers to the company's ability to overcome resistance from the status quo. The change management program at PT KAI is considered successful because it has been able to change the desires of employees from being resistant to change to acceptance. The transition from resistance to acceptance is of course through a process and people are willing to do something because it is driven by a motive. In the case of PT $\mathrm{KAl}$, the transition from resistance to acceptance was motivated by the applied reward and punishment system, and desire to improve the company's image.

Based on the research findings, there are two things that need to be considered by PT KAI in conducting change management program in the future. First, the company must continue to maintain the sense of crisis of the employees by disseminating any information related to the change program. Second, the company need to create innovative ideas that can motivate employees to continue to participate in change programs in the future and contribute to the company's progress.

\section{References}

Anderson, D., \& Anderson, L. S. A. (2001). Beyond change management: Advanced strategies for today's transformational leaders. San Francisco: Jossey-Bass Inc.

Balmer, J. M. T., and Greyser, S. A. (2003). Revealing the corporation: perspectives on identity, image, reputation, corporate branding, and corporate-level. London: Routledge.

Berger, L., Sikora A., Martin, J., \& Berger, D. R. (1994). The change management handbook: a road map to corporate transformation. USA: Irwin.

Burnes, B. (2014): Understanding Resistance to Change - Building on Coch and French, Journal of Change Management, DOI: 10.1080/14697017.2014.969755 publish by Routledge.

Collins, D. (1998). Organizational change: Sociological perspectives. London: Routledge.

Conner, Daryl, R. (1992). Managing at the speed change: How risilient managers succeed and prosper where others fail. USA: Vilard Book.

Davidson, Jeff. (2005). The complete ideal's guide to change management. Terjemahan Dudy Priatna. Jakarta: Prenada Media Group.

Harrington, H. J., Conner, D. R., \& Horney, N. L. (2000). Project change management, applying change management to improvement projects international quality advisor. USA: Mc Growhill.

Hitcher, W. (2006). The innovation paradigm. New York: Wiley

Kasali, R. (2005). Change. Tak peduli berapa jauh jalan yang anda jalani, putar arah sekarang juga. (Manajemen perubahan dan manajemen harapan). Jakarta: Gramedia Pustaka Utama.

Kotter, P. (2001). Marketing management. The millenium eEdition. USA: Prantice hall. Inc.

Lewin, K. (1951). Field theory in social science. New York: Harper \& Row.

Palmer, I., Dunford, R., \& Akin, G. (2006). Managing organizational change. A multiple perspective approach, international edition. California: McGraw-Hill. 
INTERNATIONAL JOURNAL OF ACADEMIC RESEARCH IN BUSINESS AND SOCIAL SCIENCES

Vol. 10, No. 2, Feb, 2020, E-ISSN: 2222-6990 @ 2020 HRMARS

Pole, M. S., \& Van de Ven, A. H. (2004). Handbook of organizational change and innovation. New York: Oxford University Press.

Porter, Michael, E. (1985). Competitive advantage: creating and sustaining superior performance. New York: Free Press.

Rangkuti, Freddy. (2003). Measuring customer satisfaction. Jakarta: PT. Gramedia Pustaka Utama.

Rashford, Nicholas, S. (2006). An interlevel dynamics approach. London: Routledge

Robbins, Stephen, P. (1994). Organization theory: structure, design, and application behavior, concepts, controversies, and application. Englewood Cliffs:Prentice Hall Inc.

Salaman, G., \& Asch, D. (2003). Strategy and capability: sustaining organizational change. UK: Blackwell Publishing Ltd.

Sutrisno, Edy. (2010). Budaya organisasi. Jakarta: Fajar Interpratama Mandiri. Zimmerman, Wesley W (2005). The perception of difference. The power in buying, marketing, selling, customer care. USA: The Business Enhancement Team.

\section{Journals}

Acharya, T. A., (2015) Business Process Reengineering in Commercial Banks: A Case Study of Andhra Bank. International Journal of Multidisciplin LISSN : 2349-7408, Vol II, Issue 2 (3) October.

Ayande, A. (2015) 'Better results in services: obstacles in transforming service organisations', Int. J. Strategic Change Management, Vol. 6, Nos. 3/4, pp.213-237.

Burnes, B., \& Jackson, P. (2011) Success and Failure In Organizational Change: An Exploration of the Role of Values, Journal of Change Management, 11:2, 133-162, DOI: 10.1080/14697017.2010.524655

Prouska, Rea. (2014). Creating Positive Employee Change Evaluation: The Role of Different Levels of Organizational Support and Change Participation, Journal of Change Management 07; 14(3).

Sia, S. K., \& Neo, B. S., (2008). Business process reengineering, empowerment and work monitoring. An empirical analysis through the Panopticon. Business Process Management Journal Vol. 14 No. 5, pp. 609-628 Emerald Group Publishing Limited 1463-7154.

Steven, H. A., Catherine, K., Anne, L. H., \& Beverly, M. (2017) "Resistance to change in the case of mergers and acquisitions: part 2", Industrial and Commercial Training, Vol. 49 Issue: 3, pp.139145, doi: 10.1108/ICT-05-2016-0033.

Will, M. G., (2015),"Successful organizational change through win-win", Journal of Accounting \& Organizational Change, Vol. 11 Iss 2 pp. 193 - 214. (C) Emerald Group Publishing Limited1832-5912. DOI. 10.1108/JAOC-06-2013-0056

Maqbool, S., Ismail, S. A. M. B. M., Maqbool, S., \& Hassan, S. U. (2018). Effects of Traditional Lecture Method and Multi-Sensory Approach on ELT Learners at Graduate Level. International Journal of Academic Research in Progressive Education and Development, 7(4), 488-505.

Chlapoutaki, E., \& Kostas D. Dinas. (2016). Obstacles in Implementing Critical Pedagogy. Multilingual Academic Journal of Education and Social Sciences, 4(1), 88-94.

Fery, I. (2018). The Influence of Information Technology on Application of Accrual Accounting, International Journal of Academic Research in Accounting, Finance and Management Sciences 8 (3): 194-208. 